\title{
Sikap Muslim Fundamentalis Indonesia terhadap NKRI Antara Penolakan dan Penerimaan Setengah Hati
}

\author{
Abd A'la \\ (IAIN Sunan Ampel)
}

\section{Pendahuluan}

Terbukanya kran kebebasan di Indonesia pasca runtuhnya rezim orde baru mengantarkan pemikiran dan gerakan Islam ke dalam dinamika yang -sampai batas tertentu -berbeda dengan masa-masa sebelumnya. Beragam pemikiran, dan aneka gerakan muncul ke pentas publik dengan intensitas yang cukup kuat dan penyebaran yang relatif massif. Salah satu fenomena dari hal itu adalah menguatnya pemikiran radikalisme di kalangan Muslim Indonesia. Pemikiran mereka tampak tersebar di mana-mana, dan gerakan mereka tampak terlihat di berbagai tempat. Isu yang dimunculkan pun terkadang merupakan isu yang sensitif yang tidak mungkin disuarakan atau dibawa ke ruang publik pada masa rezim orde baru.

Sejatinya jumlah kelompok mereka relatif kecil dibandingkan dengan keseluruhan umat Islam di Indonesia. Namun sama seperti di berbagai belahan dunia Muslim lain, Muslim fundamentalis di Indonesia terbukti demikian cepat dan memiliki ketrampilan dalam penggunaan teknologi komunikasi modern untuk memropagandakan pesan (Eliraz,2007) dan pemikiran mereka. Dengan demikian, fenomena yang tampak ke luar terlihat relatif besar.

Terlepas dari banyaknya penelitian yang memfokuskan kajiannya pada fenomena tersebut, gejala ini tetap menarik untuk ditelusuri dan terus dikaji. Selain ada beberapa aspek yang masih belum dicermati secara tuntas dan kritis, persoalan tersebut diasumsikan memiliki implikasi yang sangat besar bagi keberadaan Negara Kesatuan Negara Republik Indonesia (NKRI) dan kehidupan bangsa di masa-masa depan. Di antara persoalan tersisa yang perlu diangkat terkait dengan pandangan kelompok radikal terhadap NKRI. Masalah ini sangat menggugat untuk dibincang dan dikaji secara mendalam karena pada satu sisi sejumlah besar (kalau tidak semuanya) kelompok muslim fundamentalis memiliki pemikiran politik yang tampak berseberangan dengan dasar negara Pancasila, dan pada sisi yang lain NKRI merupakan realitas sosiologis, historis, dan politik yang intrinsik dengan keberadaan negara dan bangsa Indonesia.

\section{Politik dan Kemunculan Muslim Fundamentalis}

Sebelum mengurai pandangan Muslim fundamentalis di Indonesia tentang NKRI, penelusuran atas kemunculan gerakan tersebut dalam skala Internasional dan tema-tema yang diangkat sangat signifikan untuk diangkat. Bagaimanapun juga, keberadaan fundamentalisme Muslim global memiliki kaitan dengan, minimal pengaruh sangat besar terhadap, kemunculan pandangan Muslim fundamentalis di Indonesia.

Membahas tentang Muslim fundamentalis, kesimpulan Tibi tentang keberadaan kelompok ini sangat menarik untuk dicermati. la menyatakan, fundamentalisme agama bukan merupakan kepercayaan spiritual, tapi lebih sebagai ideologi politik yang didasarkan atas politisasi agama untuk tujuan sosiopolitik dan ekonomi melalui penegakan tatanan ilahi (Tibi,1998). Dalam bingkai ideologi itu, fundamentalisme agama menggunakan simbol-simbol agama, dan sekaligus memaknainya dengan arti yang baru. Simbol-simbol ini realitasnya lebih sedikit bersinggungan dengan belief, dan lebih banyak dibiaskan sebagai alat untuk artikulasi klaim sosiopolitik, ekonomi, dan budaya (Tibi,1998).

Sampai batas tertentu, warna khas tersebut juga menjadi karakteristik fundamentalisme di kalangan umat Islam. Realitas memperlihatkan, terlepas dari perbedaan pandangan dan pola gerakan, nyaris semua kelompok Muslim fundamentalis memiliki kesamaan dalam kekentalan 
pandangan mereka dalam kemenyatuan politik dan agama. Mereka menjadikan politik dan Islam sebagai visi dan orientasi gerakan mereka. Dalam ungkapan lain, politik dan agama nyaris merupakan alfa dan omega gerakan. Bahkan, dalam politik semacam itu kelompok fundamentalis tampaknya bisa eksis.

Kuatnya ideologi politik pada kelompok fundamentalis tersebut tidak terlepas dari latar belakang kemunculannya, di mana persoalan politik -diakui atau tidak -merupakan salah satu akar utama, di samping tentunya mengakar pada persoalan-persoalan lain. Aspek politik ini kemudian dirangkai dengan teologi sebagai dasar dan sekaligus justifikasi gerakan mereka. Dalam bingkai semacam itu Ikhwanul Muslimin (IM) yang didirikan pada tahun 1928 oleh Hasan al-Banna hadir ke panggung sejarah. Ikhwanul Muslimin penting untuk diangkat pertama kali karena kelompok ini nantinya mengalami ramifikasi yang memunculkan kelompok-kelompok fundamentalis lain yang sangat radikal. Dari penelitian yang ada, kita dapat melihat bahwa kemunculan IM ini mengakar pada terpinggirkannya umat Islam, khususnya Muslim Mesir, dalam dunia politik. Hal ini ditandai -menurut al-Banna -dengan tidak dilibatkannya mereka dalam proses modernisasi. Di saat yang sama ide-ide Barat yang tampaknya tidak akrab, bahkan bertentangan dengan Islam, merasuk dalam kehidupan mereka yang membuat mereka kebingungan (amstrong,2000), sehingga tidak mampu menjalani kehidupan sebagaimana harapan mereka.

Untuk menyelesaikannya, al-Banna mengharuskan penegakan Syariah dan pemberdayaan masyarakat Muslim. Al-Banna menjadikan pemikiran ini sebagai roh gerakan IM. Pada awal-awal berdirinya, pola dan strategi yang ditempuh bersifat gradual dan reformis. IM mengenalkan dan menyebarkan gagasannya melalui pendidikan dan dakwah dalam berbagai bentuknya, termasuk aktivitas pengembangan kesejahteraan masyarakat dan ekonomi, mengorganisasikan masjid-masjid, sekolah, dan klinik kesehatan (Bubalo dan Fealy,2005). Semua ini ditujukan untuk merajut dan menggapai tujuan akhir berupa al-nizham al-islami.

Namun pada masa-masa terakhir kehidupan al-Banna, aktivitas IM yang bersifat gradual mulai ditinggalkan. Kecenderungan ini muncul pada tahun 1940-an, tahun-tahun yang sangat kacau di Mesir. Saat itu demokrasi liberal di negeri Firaun tersebut gagal sehingga sebagian besar masyarakat Mesir sangat pessimis terhadap kemampuan sistem parlementer. Dalam kondisi ini, sayap-sayap militer yang mulai tumbuh di tubuh IM mengedepankan gerakan yang lebih bernuansa kekuatan dan bahkan kekerasan (Amstrong,Ibid). Radikalisme Ikhwan ini terus menguat ketika Jamal Abdul Naser dengan ideologi sosialismenya juga gagal mengantarkan Mesir menuju kemajuan yang signifikan, dan pemerintahannya tidak berhasil memenuhi harapan masyarakat Mesir.

Melihat fenomena yang terjadi ini, ada benarnya jika Euben dalam penelitiannya menyimpulkan, kehadiran Muslim fundamentalis terkait erat dengan kegagalan ideologi-ideologi alternatif, dan ketiadaan saluran politik lain. Selain itu, kesamaan identitas religius yang khas islami yang ada di Timur Tengah (Euben,2002), yaitu Islam merupakan unsur yang sama sekali tidak bisa daiabaikan. Sejalan dengan itu, modernitas yang tumbuh dan berkembang, terutama di Dunia Muslim, memiliki kelemahan-kelemahan mendasar dalam menjawab persoalan kehidupan yang dialami masyarakat. Dalam bahasa Armstrong, modernitas sering bersikap kejam terutama di negara-negara berkembang dalam tahap-tahap awal memasuki modernisasi, di mana budaya Barat yang modern dialami sebagai sesuatu yang invasif, imperialistik, dan asing (amstrong,2000). Alih-alih membawa kesejahteraan bagi seluruh masyarakat, modernisasi justru sering berimplikasi pada terjadinya peminggiran terhadap kelompok-kelompok masyarakat. Bahkan demokrasi yang sejatinya untuk penguatan kepentingan bersama, tereduksi dan membias sebagai alat justifikasi bagi segelintir elit penguasa di negara-negara berkembang untuk meneguhkan kepentingan mereka. 
Kondisi semacam itu menjadikan sebagian kelompok Muslim -meminjam bahasa El Fadl -hidup dalam perasaan kalah, frustasi dan teralienasi yang mendalam, bukan hanya dari institusi kekuasaan modern, tapi juga dari warisan dan tradisi Islam. Hal ini lalu memunculkan sikap puritanisme supremasis yang dapat memberikan kompensasi terhadap rasa kekalahan, frustasi, dan alienasi yang mereka alami dalam bentuk arogansi kebenaran diri sendiri vis-avis orang dan kelompok di luar kelompok mereka 9Fadl,2001). Mereka membuat jarak bahkan batas yang tegas antara mereka dengan orang dan kelompok lain di luar mereka.

Awal dekade 1940-an fundamentalisme Islam juga muncul dan berkembang di Anak Benua India. Pada tahun 1941, masa-masa perjuangan keras rakyat India untuk mencapai kemerdekaan, Abul A'la al-Mawdudi mendirikan partai dengan nama Jamaat-i Islami. Pendirian ini terkait erat dengan ketidaksetujuan Mawdudi terhadap All India Muslim League (Liga Muslim), partai politik terbesar setelah All India Congress yang mengeluakan resolusi menuntut berdirinya suatu negara yang terpisah dari India, yaitu negara Pakistan yang sebelumnya pernah digagas Iqbal. Pembentukan negara baru yang terpisah dari India ini memang bukan hanya mendapat penolakan dari kalangan Hindu yang mayoritas, namun juga dari kalangan Muslim tradisionalis. Mawdudi termasuk penentang cukup keras terhadap gagasan Liga Muslim. Menurutnya, selain ideologi Liga Muslim dianggap lebih menunjukkan sikap yang sekular tinimbang Islam, latar belakang keislaman para pemimpinnya juga diragukan. Lalu penyelesaian yang dilakukan adalah dengan mendirikan partai baru yang mencerminkan keislaman yang kukuh dari segala sisinya (Ihza Mahendra,1999). Pada saat yang sama hal itu juga untuk melawan modernisme dan westernasi yang merambah kehidupan.

Pandangan al-Banna dan terutama al-Mawdudi tentang modernitas berpengaruh besar pada pembentukan pemikiran Sayyid Qutb (w. 1966), tokoh utama Ikhwanul Muslim yang bergabung sejak tahun 1953 ke dalam organisasi yang dibangun al-Banna tersebut. "Mengembangkan" pemikiran kedua tokoh itu, Qutb meyakini modernitas sebagai akar persoalan yang telah menjadikan kemanusiaan mengalami kebangkrutan dalam tataran nilai yang seharusnya dapat menumbuhkembangkan kehidupan manusia secara sehat. Hal ini terlihat jelas di dunia Barat yang tidak lagi mampu memberikan nilai-nilai kemanusiaan, bahkan juga tidak dapat memberikan pemahaman tentang hakikat eksistensi itu sendiri (Qutb,Tt). Dalam perspektif Sayyid Qutb, krisis kemanusiaan ini tidak bisa diselesaikan oleh ideologi-ideologi alternatif yang ada saat itu, baik marxisme maupun sosialisme. Hanya Islam satu-satunya ideologi yang bisa mengatasi ideologi-ideologi lain dan menyelesaikan persoalan kehidupan umat. Karena itu, supremasi Islam mutlak harus ditegakkan.

Persoalan menjadi runyam ketika perasaan atau sikap supremasi tersebut mengantarkan mereka ke dalam gerakan atau perlawanan yang kadang atau bahkan sering menggunakan kekerasan yang mereka klaim sebagai jihad, dan juga melalui pembentukan kekuasaan politik. Pilihan ini justru yang sering menjadi rujukan. Hal ini tentu tidak terlepas dari politik kekuasaan yang mereka bangun yang ditransendensialisasikan melalui justifikasi teologi. Melalui konstruk semacam itu, kekuasaan yang akan mereka munculkan diklaim dan ditampakkan sebagai upaya penegakan kedaulatan Tuhan. Kehadirannya untuk melawan dan menghancurkan musuhmusuh Tuhan yang harus terus dilestarikan dari saat ke saat.

Dalam konteks itu, kita melihat pemikiran Qutb yang diejawantah dalam pola pandang sangat dikotomis. Ia meletakkan kehidupan dalam dua kutub; Islam dan Jahiliyah. Qutb bersikukuh, bahwa kehidupan yang saat itu berkembang berada dalam jahiliyah karena didasarkan pada prinsip-prinsip yang melawan kedaulatan Tuhan. Untuk itu, umat Islam tidak bisa berdiam diri, tapi harus menghancurkannya (Qutb,Tt). Pandangan ini pada gilirannya memicu kelompok IM untuk melakukan gerakan-gerakan yang bernuansa kekerasan dan mengancam kehadiran orang dan kelompok lain. 
Sepeninggal Qutb, pandangan dikotomi Islam-jahiliyahnya dikembangkan oleh Shukri Musthafa dan sektenya (yang oleh mass media biasa disebut kelompok Takfir wal Hijrah). la menyatakan bahwa seluruh masyarakat masyarakat adalah jahili dan ia menganggap mereka sebagai kafir. Karena itu, ia menyerukan kelompoknya untuk melakukan hijrah dalam rangka mempersiapkan jihad melawan masyarakat jahili tersebut (Amstrong,2000). Selanjutnya, gerakan takfir ini dikembangkan oleh Muhammad Abd Salam Faraj. la menganggap pemerintahan Mesir yang saat itu dipegang Sadat juga perlu diperangi. Pandangan ini bukan sekadar bualan di siang bolong, tapi dilabuhkan dalam gerakan-gerakan konkret. Hasilnya, ia dan kelompoknya berhasil membunuh Sadat pada tahun 1981 (Bubalo dan Fealy,2005).

Dalam bayang-bayang pandangan politik yang beroposisi biner dan supremasis itu pula, Hizbut Tahrir (HT) ikut meramaikan arena fundamentalisme agama. Sebermula didirikan, partai politik yang kelahirannya dibidani Taqiyuddin al-Nabhani pada tahun 1953 ini mendeklarasikan sebagai partai politik yang berideologi Islam $(\mathrm{HTI}, 2009)$. Dengan demikian kekentalan warna politiknya tampak dengan jelas. Partai politik ini hadir nyaris seutuhnya untuk merespon dominasi Barat. Bagi HT, Barat dengan peradaban modernnya merupakan sesuatu yang sama sekali lain yang tidak mungkin bisa disatukan dengan Islam. Bahkan lebih jauh lagi, HT melihat kehidupan modern sebagai konflik yang tak berkesudahan. Benturan peradaban antara Islam dan Jahiliyah merupakan keniscayaan yang tidak bisa ditolak. Konflik ini hadir pada masa lalu, saat ini dan akan terus berlanjut sampai kiamat. Karena itu -dalam prespektif HT -upaya yang perlu dilakukan bukanlah melakukan dialog dengan Barat, tapi mempersiapkan segala sesuatu untuk masuk dalam arena konflik $(\mathrm{HTI}, 2002)$, melakukan perlawanan terhadap Barat. Islam dan peradabannya niscaya mengalahkan Barat. Islam harus menguasai dunia dan kehidupan.

Pada gilirannya, fundamentalisme Muslim Timur Tengah juga merambah Afghanistan seiring dengan invasi Soviet ke negara Muslim tersebut pada tahun 1979. Abdullah Azzam dari kelompok IM memainkan peran penting dalam pengembangan fundamentalisme dengan mengadakan latihan dan penyebaran jihadis (Bubalo dan Fealy,lbid) di kawasan tersebut. Gerakan fundamentalisme di Afghanistan kian menguat pasca hengkangnya Soviet dari negara ini. Antara tahun 1989 dan 1998, semacam jaringan yang nantinya disebut al-Qaeda berevolusi ke permukaan melalui penguatan hubungan yang lebih formal antara Osama bin Laden dan Ayman al-Zawahiri. Dalam pandangan al-Qaeda, kehadirannya untuk melakukan perlawanan terhadap serangan yang dilakukan Amerika Serikat dan sekutunya (Ibid) yang saat itu melakukan intervensi militer di negara-negara Teluk. Dari daerah ini al-Qaeda meluaskan gerakaannya ke seantero dunia.

Kehadiran al-Qaeda menandakan bahwa genderang perang terhadap Barat sudah ditabuh nyaring dengan hasil bertubi-tubinya serangan dan kekerasan teroristik terhadap halhal yang berbau Amerika dan Barat. Bagi al-Qaeda, Barat yang jahili dan sekutu-sekutunya mutlak harus dihancurkan.

\section{Fundamentalisme Muslim Merambah Indonesia}

Arus pemikiran dan gerakan fundamentalisme mulai tumbuh kembang dengan sistematis di Indonesia ketika beberapa mantan pemimpin Masyumi mendirikan Dewan Dakwah Islamiyah Indonesia (DDII) pada tahun 1967. Tujuan pendirian lembaga yang pertama kali dipimpin Natsir ini -sebagaimana klaim Natsir sendiri -untuk mengislamkan politik nasional melalui cara-cara non politik (Latif,2005). Upaya ini tentu tidak terlepas dari kondisi Islam di Indonesia saat itu yang mendapat represi demikian kuat dari rezim Soeharto. Umat Islam dikerangkeng dan disapih dari segala hal yang berbau politik. Bahkan ada kesan kuat, rezim penguasa selalu bersikap curiga terhadap umat Muslim. 
Untuk merealisasikan tujuan tersebut, DDII melakukan pengiriman mahasiswa ke Timur Tengah yang diorganisir secara serius dan sistematis. Melalui proyek ini, mahasiswa sekembalinya dari Timur Tengah nanti diharapkan mentransmisikan ide-ide yang dapat menjadi dasar bagi proses islamisasi di Indonesia.

Dua tahun kemudian, pada tahun 1969 salah satu karya Sayyid Qutb mengenai Islam diterjemahkan ke dalam bahasa Indonesia, dan tahun 1978 karya Qutb yang lain tentang masyarakat Islam juga diterjemahkan. Hal ini memberikan peluang bagi kelompok tertentu dari Muslim Indonesia untuk mengakses dengan lebih mudah pemikiran tokoh Ikhwanul Muslimin tersebut (Ibid). Ide-ide fundamentalisme ini pada gilirannya kian dikenal luas dan menjadi anutan kalangan muslim tertentu di Indonesia.

Fundamentalisme terus mengayunkan langkah pastinya dengan hadirnya Lembaga IImu Pengetahuan Islam dan Bahasa Arab (LIPIA) yang kelahirannya didukung, bahkan dibidani oleh Natsir dan DDII-nya. Seiring dengan itu, mahasiswa yang dikirim Natsir untuk kuliah di Timur Tengah yang terpengaruh dengan pemikiran IM mulai berdatangan pada awal tahun 1980-an (Ibid). Sekembalinya ke tanah air mereka menyebarkan Islam fundamentisme Islam di tanah air, khususnya melalui masjid-masjid kampus, publikasi berkala dan penerjemahan buku-buku Islam yang bernuansa fundamentalistik. Masjid Salman di Intitut Teknologi Bandung, dan Masjid al-Ghiffari Institut Pertanian Bogor merupakan dua dari sekian masjid kampus yang menjadi pusat gerakan fundamentalisme. Namun sejauh itu, gerakan mereka lebih bersifat tarbiyah.

Fundamentalisme berkembang relatif lebih pesat lagi pada saat kelompok Darul Arqam dari Malaysia, Jamaah Tabligh dari Indo-Pakistan, dan Hizbut Tahrir yang berasal dari Yordania hadir juga di bumi Indonesia pada dawasarwa 1980-an (Ibid). Namun sikap represi rezim orba terhadap segala gerakan yang tidak sejalan dengan orde pembangunannya orba membuat muslim fundamentalis tidak bisa mengembangkan gerakan sebebas mungkin.

Runtuhnya rezim orde baru memberikan peluang besar bukan saja bagi penguatan kelompok fundamentalis, tapi juga bagi pengedepanan orientasi mereka yang bersifat politik dan kebebasan mereka dalam mengekspresikan tujuan gerakan. Misalnya saja, Jamaah Islamiyah yang didirikan pada tahun 1993 mulai menunjukkan taringnya pada akhir dasawarsa 1990-an dan tahun 2000-an melalui pelibatan mereka dalam tindakan terorisme di dalam negeri yang ditujukan kepada kelompok Kristiani dan simbol-simbol Barat. Kelompok ini selain berusaha melakukan perlawanan terhadap kekuatan Barat dan menghancurkan simbol-simbol Barat, juga meyakini perlunya islamisasi masyarakat sebagai prakondisi pendirian negara Islam (Bubalo dan Fealy,2005).

Kelompok fundamentalis lain yang hadir pada zaman reformasi di antaranya adalah Majelis Mujahidin Indonesia (MMI), dan Lasykar Jihad, sayap paramiliter dari Forum Komunikasi Ahlus Sunnah Wal Jamaah (FKASWJ) pimpinan Ja'far Abu Thalib. Sejalan dengan itu, kelompok fundamentalisme yang sudah berdiri sejak zaman orde baru, seperti Front Pembela Islam (FPI) dan Komite Indonesia untuk Solidaritas Dunia Islam (KISDI), menjadikan kehadiran era refomasi sebagai momen untuk memperkuat posisi dan memperkeras gaung mereka.

\section{Negara dalam Perspektif Muslim Fundamentalis}

Berdasar pada kemunculan beragam gerakan muslim fundamentalis kontemporer, kita melihat bahwa aspek politik merupakan hal yang sama sekali tidak bisa diabaikan. Terlepas dari perbedaan intensitas pada tiap-tiap kelompok fundamentalis, unsur politik merupakan benang merah yang merangkai semua kelompok fundamentalisme muslim di era modern hingga sekarang. Aspek politik ini dikemas, atau dijustifikasi dengan teks-teks suci, atau doktrin-yang diklaim sebagai ajaran -Islam. 
Sebagai implikasi lebih jauh dari hal itu, negara menjadi salah satu tema utama yang nyaris intrinsik dengan wacana dan gerakan kelompok tersebut. Oleh karena politik sebagai bagian dan orientasi gerakan mereka dimuati dengan aspek-aspek teologis (atau sebaliknya), negara dalam perspektif mereka juga lekat dengan nuansa atau simbol-simbol agama. Bahkan sampai batas tertentu, negara dianggap sebagai salah satu sisi dari mata uang yang sama. Sisi lainnya adalah agama itu sendiri.

Dalam pemikiran al-Banna, keharusan keberadaan negara Islam serta bentuknya belum tampak terang benderang. Hasan al-Banna hanya bersikukuh agar bangsa-bangsa Muslim bersatu, serta melakukan pembebasan terhadap dominasi asing. Pada saat yang sama, Islam perlu dipromosikan sebagai perdamaian dan persaudaraan ke seluruh dunia. Namun pandangannya tentang Islam sebagai total way of life (Amstrong,2005) mengindikasikan keharusan tegaknya negara yang seutuhnya dapat menjalankan misi tersebut. Dalam bahasa lain, bagi al-Banna berdirinya sebuah negara yang mampu menegakkan Syariat Islam merupakan tujuan yang harus dilabuhkan dalam kehidupan umat Islam.

Keniscayaan tegaknya negara Islam juga merupakan tujuan yang diperjuangkan alMawdudi melalui partai politik Jamaat-i Islami. Negara Islam menurut al-Mawdudi-sebagaimana dikutip Mahendra -adalah negara yang hanya memberikan raunga bagi kedaulatan Tuhan dengan Syariah Islam sebagai hukum tertinggi. Dalam bingkai itu, pemerintah sebagai pemegang amanah Tuhan yang bertugas untuk melaksanakan kehendak-Nya, serta tidak melakukan tindakan yang melampaui batas-batas yang ditetapkan Tuhan (Mahendra,1999).

Pandangan al-Mawdudi itu kemudian mempengaruhi pemikiran Qutb tentang negara. la meniscayakan sistem pemerintahan yang harus bertugas menegakkan al-nizam al-islami yang didasarkan pada kedaulatan Tuhan semata, yang sama sekali tidak bisa dicampur-adukkan dengan lainnya (Qutb,1993). Namun berbeda dengan al-Banna, Qutb menegaskan keniscayaan umat Islam untuk terus menerus melakukan pembebasan manusia di seluruh penjuru dunia dari segala bentuk kedaulatan selain kedaulatan Allah. Tugas ini harus dilaksanakan sehingga Islam menjadi satu-satunya agama di alam raya. Dalam konteks ini -menurut Qutb -jihad memiliki arti moralnya yang sejati (Qutb,1993). Melalui pandangan semacam ini radikalisme Qutb menemukan titik labuh nyata.

Langsung atau tidak langsung, pandangan radikal tersebut berpengaruh besar pada gerakan Ikhwanul Muslimin. Dalam masa-masa kehidupan Qutb tersebut, IM selalu melakukan gerakan perlawanan terhadap pemerintahan Mesir. Bahkan pada saat itu tumbuh subur jaringan terorisme yang memiliki hubungan atau bagian dari Ikhwan al-Muslimin yang berusaha menggulingkan pemerintahan Naser, dan bahkan berusaha membunuhnya. Dalam pandangan mereka, negara Mesir di bawah pemerintahan Naser bukan negara yang mengimplementasikan kedaulatan Tuhan.

Dalam bayang-bayang radikalisme Qutb itu, gerakan seperti Takfir wal Hijrah berusaha menggulingkan pemerintahan Anwar Sadat, pengganti Naser. Mereka mengedepankan aksi-aksi kekerasan yang sarat dengan nuansa terorisme. Melalui aksinya itu, kelompok ini melakukan pembunuhan Presiden Anwar Sadat. Bagi kelompok semacam ini, keniscayaan pendirian negara Islam tampaknya bukan lagi tujuan utama. Justru yang mereka tekankan adalah penggunaan kekuatan untuk menghabisi orang atau kelompok yang dianggap sebagai musuh Islam, kendati orang tersebut seorang muslim.

Di tangan Hizbut Tahrir, bentuk negara secara konseptual mengalami konkretisasi signifikan. Al-Nabhani menjelaskan, negara yang harus ditegakkan adalah negara Islam, satusatunya negara yang harus mengembalikan Islam sebagai way of live yang didasarkan pada aqidah Islam, mengimplementasikan Islam dalam masyarakat, dan membawa misi Islam ke 
seluruh dunia (Al Nabhani, 1998). Dalam perspektif Hizbut Tahrir, negara Islam yang disebut Dawlah Khilafah ini merupakan negara kesatuan, bukan negara federasi, bagi seluruh umat Islam di dunia ini. Dawlah Khilafah hanya satu-satunya negara Islam yang melingkupi keseluruhan umat Islam di dunia.

Al-Nabhani, sang pendiri HT, menegaskan, penegakan Dawlah Khilafah merupakan kewajiban bagi seluruh umat Islam. Setiap muslim berada dalam kungkungan dosa selama mereka tidak berjuang untuk mendirikan negara Islam tersebut (Nabhani,1998). Karena itu, kapan dan di mana saja, Dawlah Khilafah harus ditegakkan.

Terlepas dari ungkapan yang berbeda, pemikiran hampir semua Muslim fundamentalis mengenai negara berlabuh dalam satu dermaga yang sama. Mereka semua memainkan orkestra yang senada dalam alunan irama keniscayaan negara Islam. Bahkan bagi kaum fundamentalis, Islam bukan sekadar agama, tapi sekaligus juga negara sehingga kedua unsur ini sama sekali tidak bisa dipisahkan.

\section{NKRI di Mata Muslim Fundamentalis}

Ketika fundamentalisme menjadi pola keberagamaan sebagian Muslim Indonesia, maka pandangan mereka mengenai politik dan negara nyaris tidak berbeda sama sekali dengan pandangan kelompok fundamentalis di negara lain. Bahkan mereka -sampai batas tertentu -sekadar mengimpornya dari muslim fundamentalis global dan disemaikan di bumi Indonesia. Dalam ungkapan yang lebih jelas, negara Islam merupakan tujuan yang harus diperjuangkan dari saat ke saat.

Hal ini tampak jelas dari pandangan Hizbut Tahrir Indonesia yang melihat Dawlah Khilafah merupakan kebutuhan dan perjuangan penegakan Dawlah Khilafah sebagai kewajiban bagi setiap Muslim. Melalaikan tugas ini adalah dosa (HTI, 1999). Negara Islam merupakan tujuan partai politik ini yang sampai saat kapan pun upaya ini melalui tahapan-tahapan perjuangannya niscaya untuk diwujudkan. Dengan pandangan ini yang disebutkan dengan jelas dalam Manifesto Partai, HTI sejatinya menolak keberadaan NKRI. Mereka dipastikan sedang menunggu saat yang tepat untuk menghancurkan NKRI dan pada saat yang sama menggantinya dengan dengan Dawlah Khilafah.

Penolakan mereka terhadap Negara Kesatuan Indonesia saat ini dirupakan dalam bentuk penolakan setengah hati. Dikatakan demikian, karena kendati mereka pada hakikatnya menolak, mereka dalam realitasnya tetap mengambil hak-hak yang senyatanya menjadi hak warga negara Indonesia. Padahal dengan penolakan mereka terhadap NKRI, mereka seharusnya tidak berhak lagi untuk mengklaim sebagai warga negara Indonesia. Seiring itu, hak-hak yang dimiliki warga negara dengan sendirinya menjadi hilang dari mereka.

Hingga saat ini, upaya pendirian negara Islam yang dilakukan HTI di Indonesia lebih menampakkan diri dalam gerakan yang bersifat dakwah non-violen. Namun gerakan ini bersifat sementara. Sebab sebagaimana tahap-tahap dakwah mereka (HTI,1999), gerakan HTI di Indonesia masih dalam tahap kedua. Jika nanti mereka sudah berada dalam tahap ketiga, yang intinya adalah pengambil-alihan kekuasaan, mereka dipastikan akan melakukan gerakan yang rawan dengan penggunaan kekuasaan.

Visi tegaknya negara Islam juga dianut oleh MMI. Namun berbeda dengan HTI, organisasi pimpinan Abu Ja'far Ba'asyir tersebut tidak mengharuskan nama khilafah, dan tidak mempersoalkan bentuk dan nama. Hal yang penting adalah pengawalan negara bagi penegakan Syariat Islam dan dapat mempersatukan umat Islam (Atadlal,2005). Sejalan dengan pandangannya ini, MMI menolak demokrasi dan tidak setuju dengan nasionalisme karena ini 
merupakan produk Barat (Ibid). Sikap ini mempertunjukkan secara jelas bahwa MMI sebenarnya juga menolak NKRI karena negara ini secara terang benderang menganut sistem yang ditolak MMI, yaitu demokrasi dan nasionalisme.

Pandangan yang lebih lunak secara konseptual dianut oleh FPI. Menurut Habib Rizieq, ketua FPI (sebagaimana disampaikan kepada Khamami Zada), bentuk negara apa pun tidak menjadi persoalan sepanjang masyarakat Islam memperjuangkan penegakan Syariah Islam (Zada,Tt). Namun, tuntutan pelaksanaan syariah Islam ini mengandung kerawanan tersendiri terhadap NKRI yang berdasar Pancasila. Sebab implementasi Syariah ini bisa saja mengundang pertentangan dengan Undang-Undang Dasar ketika penekanannya pada formalisasi dan simbolisasi agama yang menegasikan keragaman agama sebagaimana dianut Indonesia. Alhasil, penerimaan mereka terhadap NKRI terkesan kuat bersifat setengah hati.

Dari pandangan kelompok-kelompok Muslim fundamentalis mengenai negara tersebut kita dapat menyimpulkan bahwa bentuk dan ekspresi penolakan atau penerimaan kelompok Muslim fundamentalis terhadap NKRI terlihat sangat beragam. Sebagian kelompok menolak NKRI melalui cara-cara yang awalnya tidak menggunakan kekerasan. Yang lainnya, menerima NKRI tidak dengan sepenuh hati. Namun sebagian besar yang lain menjadikan kekerasan sebagai pola dan strategi untuk menolak keberadaan NKRI. Terorisme yang sejak tahun ketiga dekade 2000-an marak tidak diragukan lagi merupakan bentuk atau cara pengungkapan penolakan mereka terhadap negara Indonesia tersebut. Dalam tataran ini, kita melihat Jamaah Islamiyah dan turunannya yang diduga keras berada dalam beberap aksi terorisme di negeri ini.

Pada umumnya mereka menolak keberadaan negara ini dengan alasan negara ini tidak sesuai dengan Syariat Islam, seperti nasionalisme, atau demokrasi yang dianut NKRI. Dua hal ini sangat ditolak kelompok fundamentalis. Selain itu, pemerintah yang mengawal negara ini bukan pemerintah Islam, kendati orang-orangnya Muslim. Bahkan mereka merupakan pengikut negara-negara Barat yang dalam anggapan mereka adalah kafir.

\section{Penutup}

Negara Islam, minimal formalisasi Syariah Islam, sebagai tujuan yang ingin dicapai hampir semua kelompok fundamentalis Muslim di Indonesia merupakan fakta yang sulit untuk dibantah. Masing-masing memiliki skala prioritas dan cara tersendiri untuk pencapaiaannya. Namun terlepas dari perbedaan itu, negara Islam atau formalisasi simbol-simbol keagamaan yang harus melekat di dalam suatu negara pada akhirnya sulit untuk disatukan dengan konsep NKRI. Bahkan negara Islam atau formalisasi Syariah versi mereka nyaris dipastikan bertentangan dengan NKRI.

Oleh karena itu, sebelum semuanya terlambat, pemerintah perlu bekerjasama dengan unsur-unsur masyarakat untuk melakukan penyikapan terhadap hal tersebut secara arif, serta perlu merumuskan dan mengambil langkah-langkah sistematis yang dapat menjamin keberlangsungan NKRI. Segala upaya yang akan diambil niscaya diletakkan dalam bingkai tatanan hukum yang mencerminkan keadilan substantif, dan kemaslahatan bersama.

Sejalan dengan itu, organisasi-organisasi keagamaan dituntut untuk mengembangkan Islam substantif yang berwajah Indonesia. Islam yang perlu ditumbuh-kembangkan adalah Islam yang berlabuh kokoh pada sumber dan tradisi Islam dan sekaligus dapat menyapa dan menyantuni realitas kehidupan yang ada di Indonesia. 